in time and space. The strong evidence for forest environments comes from other sites: Songhor and Koru, based on abundant mammalian faunas, and Mfangano, based on the fruits of tropical forest trees. The evidence for forest at Rusinga is based on localized outcrops of forest faunas, abundant woody climbers, which typically would have been growing locally along water courses, and leaves with apparent (not yet analysed) forest affinities. The so-called fruit-and-nut bed, which Walker mentions several times as providing evidence of forest, is actually dominated by plant species with deciduous woodland affinities. The idea of Proconsul as a slow climber subsisting mainly on a diet of soft fruits, as indicated by its functional morphology, is less viable if it lived in a deciduous woodland environment, rather than a forest.

Walker's semi-popular account of this important fossil ape will be an accessible and entertaining read for the educated layman. It will also be a useful guide to students learning about how research is conducted, although they need to be aware of the idiosyncracies in this highly personalized account. We can live in hope that Walker will do justice to his great abilities and will yet produce a definitive account of this ape in the tree.

Peter Andrews is in the Department of Palaeontology, The Natural History Museum, Cromwell Road, London SW7 5BD, UK.

\section{The evolution of scientific thinking}

\section{Reef Madness: Charles Darwin, Alexander Agassiz, and the Meaning of Coral \\ by David Dobbs}

Pantheon Books: 2005. 306 pp. \$25

\section{Rachel Wood}

Reefs have long fascinated natural historians and geologists for their unearthly beauty, as well as their ability to produce prodigious amounts of carbonate sediment. Yet reefs offer more than their share of paradoxes. How do coral-reef islands seemingly grow from great depths in the middle of the oceans? What controls the production of all this limestone? And why do so many reefs form necklaces strung across the Pacific? These questions troubled the minds of nineteenth-century scientists and philosophers. The long, tortured and often sad history of how the 'coral reef problem' was finally solved is laid bare in this eloquent and thoughtful book.

We are first introduced to the key figures: Louis Agassiz, his son Alexander and Charles Darwin. The book explores in detail the meteoric rise and fall of the arrogant, narcissistic and charismatic Louis, and his relationship with his shy and diligent son. Louis, a palaeontologist, was the first to propose that an ice age could explain many features of the Earth's surface. In the midnineteenth-century United States, which was hungry for pioneering personalities that embodied the spirit of a young nation, Louis' enormous energy and persuasive vision enabled him to found many scientific institutions that still thrive today. Darwin, by contrast, is presented as a distant figure, more a man with a following than a personality.

It was Louis' failure to embrace the implications of Darwin's Origin of the Species, instead tenaciously holding on to his idealistic logic that God had created all species whole and immutable, that toppled him from his pedestal in American scientific and Boston blue-blood society. In just five years Louis was transformed from being seen as the prince of US science to an archaic reactionary.

As a young man, Alexander was caught between paternal loyalty and a great personal need for objective and careful analysis. He rejected his father's florid unscientific style but was equally unhappy with Darwin's theorizing, which was based, as Alexander saw it, on equally unacceptable flights of imagination, rather than on the tireless compilation of meticulously observed facts.

Darwin had been greatly influenced by the geologist Charles Lyell, whose major tenet was that geological structures, rather than being the result of past catastrophes, were instead formed by the constant action of slow and gradual processes observable today. It is easy to see how such thinking led to Darwin's formulation of another timebased phenomenon: the origin of multiple species through common descent by means of natural selection. Darwin's observation of Pacific reefs, together with his harrowing experiences of the Earth-moving forces of earthquakes during the voyage of the Beagle, led him to propose that oceanic reefs and atolls were formed on subsiding foundations, such as volcanoes. His imaginative intellect saw here another result of small changes that could account for otherwise complex patterns: that there was a dynamic relationship between the reefs and their foundations that seemed to shape them. But proof for this theory was there none.

So the stage was set for a century-long battle for the roles of empiricism, theorizing and imagination in scientific endeavour. In 1876, the Scottish oceanographer John Murray had put forward an alterative coral- reef hypothesis. He proposed that reefs grew not on their own debris, but on the accumulation of sediment derived from plankton and other non-coral skeletons. Alexander Agassiz was immediately drawn to this idea: it was born of neither his father's idealism nor Darwin's over-simple theorizing, but seemed instead to be based firmly on observable fact. Alexander, grief-stricken by the early loss of his wife and other relatives, had finally found his raison d'être: to disprove Darwin's theory.

Made hugely wealthy from the ownership of copper mines, Alexander was able to embark on a massive programme of travel. For decades he made detailed observations of all the known coral reefs. He was convinced that each reef was a
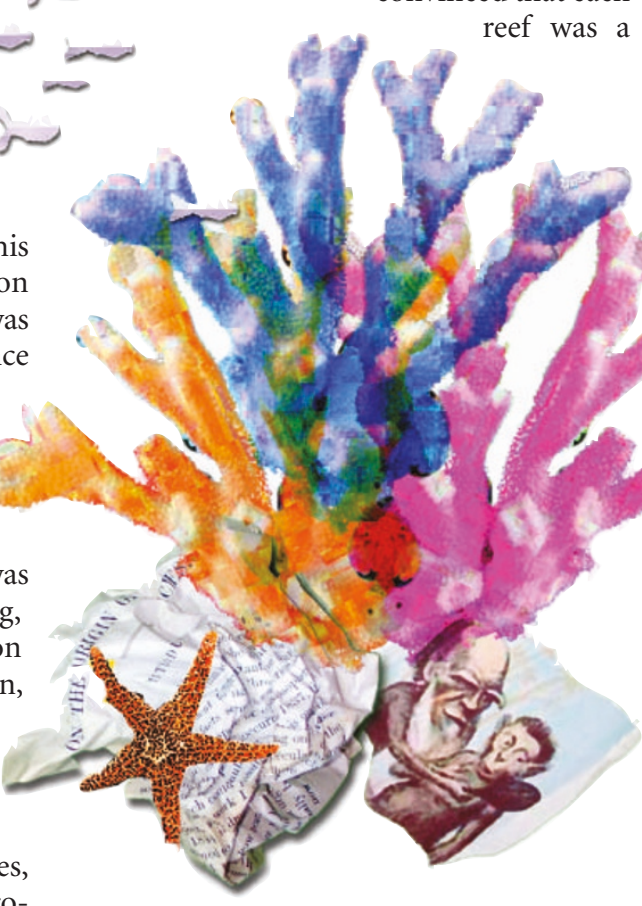

unique outcome of forces that combined in different ways: no single grand theory was required. By 1902, he believed he had proved Murray's theory. Yet astonishingly, after his death in 1910, no manuscript that summarized his massive accumulation of observations was ever found. It seems that for Alexander, the chase was everything.

The truth is that there were never enough facts to go on. All the protagonists had died long before the origin of reefs was resolved by deep drilling in the 1950 s. The penetration of Eniwetok atoll down to its volcanic foundations revealed some 1,500 metres of coral reef limestone, proving Darwin right.

Reef Madness is more than a narrative about the victory of empiricism, the power of observation as the evidence of truth, over the philosophy of belief. It is also a beautiful illustration of how theories can, or must, be built slowly and painfully,brick by brick, by a dynamic combination of both imaginative leaps and factual observation. It would be foolish to think that this debate has ended: as 
the author points out, 150 years later, over half of Americans continue to believe that God has either created species or directs evolution in some way. It seems that science and the human condition will always need a beautiful idea.

Rachel Wood is at Schlumberger Cambridge Research and in the Department of Earth Sciences, University of Cambridge, Downing Street, Cambridge CB2 3EQ, UK.

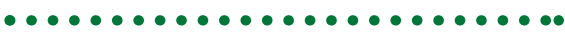

With the future in mind

\section{The 21st-Century Brain:}

Explaining, Mending and Manipulating the Mind

by Steven Rose

Jonathan Cape: 2005. 352 pp. $£ 20$

Published in the US as The Future of the

Brain (Oxford University Press, \$28)

\section{John C. Marshall}

Steven Rose is both a distinguished neuroscientist and a conscientious citizen who has long been active in left-wing causes. Reflecting this duality, The 21st-Century Brain is surely the only book on neuroscience in which the index entry for 'consciousness' includes both 'class' and 'feminist' as subheadings. It is also the only one that the author says "is definitely not about offering some dramatic new 'theory of consciousness'". The omens, then, are good.

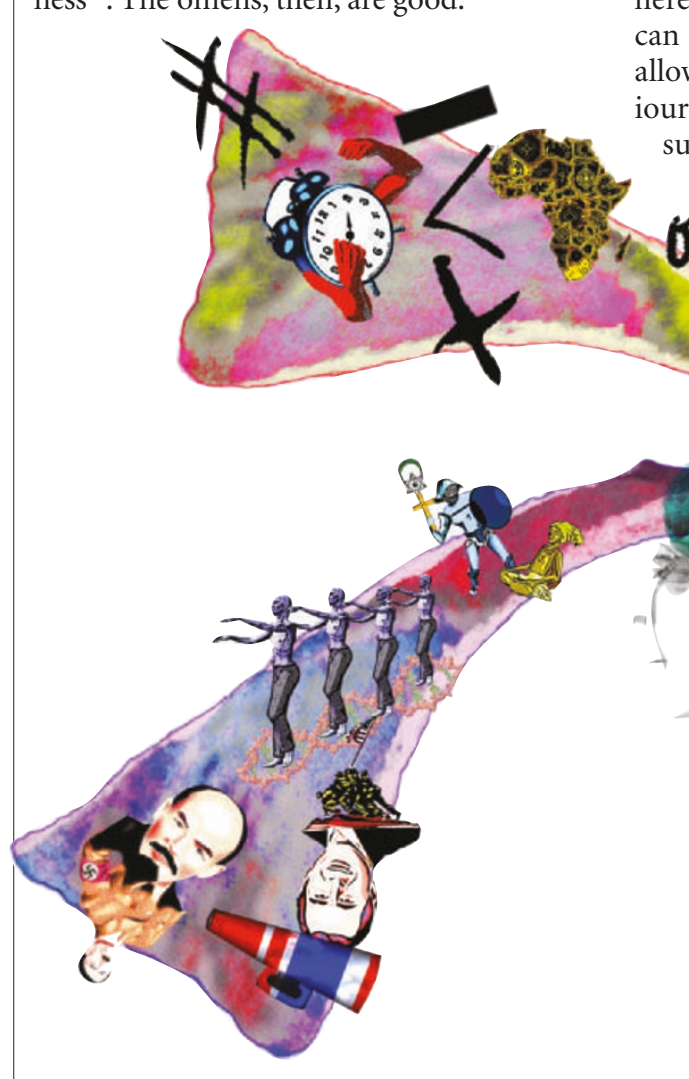

Rose offers a fairly comprehensive, albeit simple, account of our current understanding of the brain, of where research might lead us next, and of the ethical issues that already arise from the application of neuroscience and that will multiply rapidly in the near future.

He takes us on the evolutionary journey from the metabolic soup of protocells in sea water to the 100 billion richly interconnected nerve cells that make up the human brain. Yet all the while he insists that the physical brain enables, but does not determine, mental life. The locution allows Rose to stress how individual life histories are "shaped by culture, society and technology", although this observation, however true, does little to bridge the gap between brain and mind.

Indeed, when the chips are down, Rose's position is indistinguishable from one form of dualism: "In the lab we can all aspire to objectivity, examining the workings of other brains — or even imagining our own — yet we go home in the evening to our subjective, autobiographical world, and aspire to make personal sense of our lives and loves." Neuroscientists, he declares, "must learn to live with this contradiction". He is even prepared to believe that the natural sciences are perhaps intrinsically incomplete and must be complemented by the kinds of knowledge we gain from the arts and humanities. Certainly, he sees no reason to believe E. O. Wilson's claim that art, literature and music arose as evolutionary strategies for attracting mates.

I have every sympathy for Rose's position here, but I wonder whether neodarwinism can survive in its present form if we are allowed to pick and choose which behavours (or their underlying genes) have been subject to natural selection. For example, Rose is convinced that "language evolves to fit comfortably with preexisting brain mechanisms, and the brain evolves to accommodate these new linguistic potentials". But there is no more hard evidence for these claims than there is for the notion, roundly dismissed by Rose, that human nature was fixed in the Pleistocene 600,000 to a million years ago. At some point we may understand how the roughly $1 \%$ genetic difference between chimpanzees and humans is responsible for such a cognitive gulf between the two species, including the capacity for language; at present we are in the realm of 'just so' stories.

Even with respect to Rose's own area of research - learning and memory - the lack of detail in The 21st-Century Brain makes the line of argument confusing to the outsider. Rose notes that "because non-human animal brains work very much in the same way as do our own, I am able to work with experimental animals to analyse the molecular and cellular processes that occur when they learn some new skill or task". A little later, however, we discover that "different species have widely differing skills" in what they can and cannot learn. No doubt the two claims are compatible, but it would have been helpful to have the reconciliation spelled out. The section on autobiographical memory only confuses the issue further. Rose reports the position of the psychologist Endel Tulving that memories are not permanently stored in the brain, but rather "actively called into being, in the process of recall". I suspect that Rose would disagree, but sadly he fails to comment.

In the concluding chapters, Rose moves into the controversial realms of mental illness, psychopharmacology, thought control, neurogenetics and biocybernetics. These pages are appropriately sceptical of the motives of drug companies, politicians and generals. Rose argues convincingly that the distinctions between mad, bad and justified violence depend less on the supposedly diseased or normal structure and activity of the brain than on who wields the power. The main issues for "ethics in a neurocentric world", the title of Rose's concluding chapter, seem to have more to do with politics than neuroscience. This chapter is a welcome reminder that we should keep our eyes and ears open, and make our voices heard. John C. Marshall is at the Neuropsychology Unit, University Department of Clinical Neurology, Radcliffe Infirmary, Woodstock Road, Oxford OX2 6HE, UK. 